Johns Hopkins University has launched the Baltimore Architecture Project-a collaborative effort that will bring together online documents relating to Baltimore's architectural history that are now scattered among libraries, churches, hospitals, and museums throughout the city and elsewhere-with the help of a $\$ 40,000$ grant from the Gladys Krieble Delmas Foundation and a \$10,000 award from the Middendorf Foundation. The pilot phase of the project features biographical information about Baltimore's most prominent architects and primary source materials pertaining to the city's architecture. Project partners include Towson University, the Athenaeum of Philadelphia, and the Baltimore Architecture Foundation. To date, profiles of more than 500 Baltimore architects and engineers have been entered into the database, which covers the years 1850 to 1945 . To visit the Baltimore Architecture Web site, visit baltimorebuildings. org.

\section{The Southeastern Library Network} (SOLINET), in partnership with the HBCU Library Alliance and the Association of Southeastern Research Libraries (ASERL), received a \$20,000 grant from the Andrew W. Mellon Foundation to support a pilot test of an exchange program for librarians from Historically Black Colleges and Universities (HBCU). The pilot will place librarians from HBCUs at five southeastern research libraries for two weeks during the summer of 2006. Exchange librarians will be selected through an application process and matched to an ASERL host based on an identified strategic issue that the librarians and the HBCU library wish to advance within their campuses.

Ed. note: Send your news to: Grants \& Acquisitions, C\&RL News, 50 E. Huron St., Chicago, IL 60611-2795; e-mail: agalloway@ala.org.

\section{Acquisitions}

Radio and television personality Art Linkletter has donated his archives to San Diego State University (SDSU) Library and Information Access. Linkletter who graduated from SDSU in 1934, hosted two of the longest running shows in broadcast history: House Party and People are Funny. Linkletter is also a bestselling author, having penned 23 books, including Kids Say the Damdest Things, which is one of the top 14 bestsellers in American publishing history and was number one for two consecutive years. The Linkletter Collection features 13 boxes of books, scrapbooks, pamphlets and magazines, reel-to-reel tapes, keys to cities, trophies, and dozens of photographs and other memorabilia. Included in one of the scrapbooks are advertisements of products Linkletter promoted, such as Bulova Jewelers, CBS Radio Network, General Electric, and Kellogg's Frosted Flakes. Another scrapbook includes materials, such as newspaper clippings, proclamations, and photos, from Linkletter's anti-drug abuse campaign in Appleton, Wisconsin. Scripts from his early television shows, CBS press releases, and a promotion package for House Party are other items that offer a glimpse behind the scenes of Linkletter's long career from the 1940s to the 1960s..

UCLA has received the Richard and Mary Rouse Collection of Medieval and Renaissance Manuscripts. The gift from Richard Rouse, UCLA professor emeritus of history, and Mary Rouse, former editor of Viator, includes 113 manuscripts and 78 manuscript leaves and documents. The collection includes examples of nearly every type of manuscript and offers scholars a broad picture of manuscript culture in the later Middle Ages and Renaissance. Individual items come from Bohemia, England, France, Germany, the Netherlands and Spain, with texts in Latin, Czech, Dutch, French, German, Italian, and Middle Eng- 
lish. Subjects covered include history, law, medicine, music, pastoral care, philosophy, science, and theology. The earliest item dates from the ninth century and the latest from the 17 th century, with the majority coming from the period 1200 to 1500 . Among the more remarkable manuscripts in the gift is an illuminated parchment roll eight feet long, containing the genealogy of the kings of England from Aethelbert, first king of Kent (589-610), to Richard II (1377-99). Many of the manuscripts in the gift can be seen in the online exhibit of selections from the Rouse Collection at www.library.ucla.edu/libraries/special /scweb/rouse/rouseindex.htm.

\section{More than $\mathbf{6 0 0}$ rare books on British history}

have been given to Appalachian State University by alumnus Bill Rhinehart and his wife Maureen. The Rhineharts, who had collected the books for several decades, also donated their collection of some 600 modern books related to the subjects of the rare books. The rare book collection, which spans the 16th to the 19th centuries, grew from their interest in the British monarchy, aristocracy, and political history. The oldest book in the collection is Sir John Hayward's The First Part of the Life and Rraigne of King Henrie the IIII, published in 1599. The collection complements the library's holdings regarding British history, including a complete run of papers from the House of Lords and House of Commons on microfilm.

\section{Rutgers University's Institute of Jazz} Studies (IJS) has received an unprecedented number of collections during the past year, including two of the largest donations of recordings in its 54-year history. One of the donors is Donald Lass, former editor and publisher of the Asbury Park Press, who donated his collection of 10,000 LPs (long-playing records) — the single largest collection of recordings ever received by IJS. The collection includes almost every major swing and mainstream jazz artists with a strong concentration in the records of New Jersey native Count Basie. Another large record collection was the gift of the late Nathan Solomon, a Los Angeles jazz record collector, who bequeathed his collection of 5,000 discs to IJS late in 2004. Solomon, who was a fan of all types of jazz spanning the late 1920 s to the 1990 s, had wide contacts among collectors and dealers and was able to obtain many obscure issues from Europe and Japan. IJS also received a unique collection of more than 5,000 jazz 78s, donated by a veteran New Zealand collector, Barry W. Owen. In December 2005, IJS received the first two installments of the archives of the late Rudi Blesh, a pioneer jazz historian and author of several widely read works, including Shining Trumpets and They All Played Ragtime. In addition, IJS is now the repository for the archives of two major New York jazz festivals: the Vision Festival and the Charlie Parker Festival. For the past decade, the Vision Festival has been New York's premier yearly showcase for avantgarde jazz and improvised music, while the Charlie Parker Festival has presented jazz luminaries in free concerts every August for the last 13 years.

\section{The papers of poet Wesley McNair have} been acquired by Colby College in Waterville, Maine. McNair, one of New England's notable poets, has served as a visiting professor of English at Colby College and is now professor emeritus and writer-in-residence at the University of Maine-Farmington. He is the author of more than a dozen books, including eight volumes of poetry, two collections of essays, and four edited anthologies. In 2005, he received his second Rockefeller fellowship, and he has held grants from the Fulbright and Guggenheim foundations, a National Endowment for the Humanities Fellowship in literature, and two National Endowment for the Arts fellowships. The McNair collection is a rich, eclectic body of materials that contains early writings, manuscript drafts, first appearances, photographs, and extensive correspondence with literary peers. The McNair papers comprise more than 100 linear feet and will continue to grow through annual accruals. $\pi$ 